\title{
Yes We Can? \\ The Promises of Affect for Queer Scholarship
}

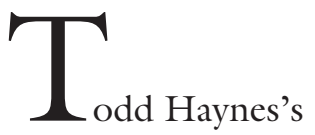

short film, Dottie Gets Spanked (1994), is a narrative about shame and identity, set in pre-hippie Long Island. Six-year-old Steven Gale wears red shoes and adores Dottie Frank, the raunchy star of a I Love Lucy-like television sitcom. The narrative scenarios of The Dottie Show feed Steven's imagination, finding vivid expression in his drawings and dreams. While Steven's mother encourages his passionate fandom, his father disapproves and other schoolchildren regard him as weird. Visiting the TV studio set, Steven is mesmerized by a scene where Dottie gets spanked by her husband, seeing his adored star switching between positions of submission and ultimate authorial control. Back home he re-lives this experience by drawing the spanking scene with his crayons and colouring it in shades of red, yellow and orange. Steven's emotions vary from defiant enthralment to shame, but his father's expressionless face when seeing the drawing confirms both the sexual charge and the 
queerness of his fantasy. After a nightly dream featuring himself in scenarios of masochistic pain and pleasure, Steven goes to the backyard of the suburban home and buries the shamefully passionate drawing. But as the title of the film, a play upon Sigmund Freud's 1919 essay "A child is being beaten" implies, fantasies have a stronger hold than that. In Haynes's film, the importance of fantasies for the structuring of sexual and social subjectivity is underlined by the fact that Steven buries his drawing and, by implication, his illicit fantasy and desire, wrapped in tinfoil, ironically making sure that it will not moulder. Beyond a portrait of an effeminate boy, hence, Dottie Gets Spanked depicts the formation of a socio-sexual subject (de Lauretis 1994) in terms of a tension between interiority and exteriority, as a psychic life structured by temporality and history of desires and negations. In so doing, the film coincided interestingly with concurrent developments in 1990s queer scholarship and, in particular, with the development later termed as a "turn to affect".

In 2007, South Atlantic Quarterly published a special issue with the appropriately provocative title "After sex? on writing since queer theory". While suggesting that "queer theory" might be a phenomenon of the past, the aim of the collection was to take stock of the field by inviting wellknown contributors to reflect upon what, in their research, is and is not queer. In the introduction, the editors, Janet Halley and Andrew Parker, describe the contemporary research field by identifying and juxtaposing "the so called anti-social thesis" attributed to Leo Bersani and Lee Edelman, and "the turn to affect", associated with Eve Kosofsky Sedgwick, Lauren Berlant and Ann Cvetkovich (Halley \& Parker 2007:428). While Lee Edelman lives up to his reputation by proposing "the wholesale embodiment of the anti-social by nonreproductive sexualities" and propagating for "a project that's willing to forgo the privilege of social recognition" (Edelman 2007:470, 473), the South Atlantic Quarterly special issue does not (even attempt to) do justice to the existing abundance of queer scholarship on affect.

In this essay, I argue in favour of Halley's and Parker's identification of "a turn to affect" as an important phenomenon within queer thinking but, at the same time, I question their casting of it against "an antisocial thesis". In my analysis, the description of the field of queer analysis as juxtaposition between these two does not hold. On the one hand, despite different emphases, the same deconstructive impulses and psychoanalytical frameworks inform both approaches and their respective key theorists. On the other hand, the "turn to affect" needs to be understood as anything but a unitary theoretical, methodological or political move, featuring, rather, a range of incommensurate critical positions. Furthermore, it will be argued, Halley's and Parker's description is misleading as it clouds other, more fundamental lines of division within queer scholarship. Turning to Eve Kosofsky Sedgwick's forceful and influential writings on affect, this essay unpacks the notion of "turn", rendering visible both a particular politics of concept in operation and the conceptual and methodological tensions inhabiting the notion.

\section{AFFECT AND THE POLITICS OF IDENTITY}

Todd Haynes's film was released a year after the first issue of GLQ: A Journal of Lesbian and Gay Studies was published, featuring ground-breaking articles by Eve Kosofsky Sedgwick and Judith Butler. The two articles of the opening issue, Sedgwicks's "Queer performativity: Henry James's The art of the novel" and Butler's "Critically queer", written partly in dialogue with one another, established performativity as a key concept for thinking about queer, and vice versa. Whereas Butler's article serves as a 
revision and further develops her arguments on performativity in Gender trouble (1990), Sedgwick's reading of Henry James argued for reconceptualizing shame for the purposes of queer scholarship and activism. While often rejected as a "toxic" feeling to be turned into pride, Sedgwick argued for an understanding of shame as pivotal to understanding both identities in general and queer identities in particular. Furthermore, she argued for conceptualizing shame simultaneously as a foundational, identity-forming affective experience and a transformational, antiidentitarian energy. In retrospect, Sedgwick's article has with its follow-ups been immensely inspiring for queer scholars. Furthermore, its complex argumentation has encouraged conflicting readings, thus rendering visible the variety of theoretical and methodological positions that characterize queer theory today. ${ }^{1}$

In her article on queer performativity, Sedgwick draws from developmental psychology to contend that shame is "the keystone affect" in socialization of individuals. Shame defines a space of identity, "the space wherein a sense of self will develop" (1993:5). With this gesture, Sedgwick distances herself from contemporary self-help literature and conservative readings of shame but, in evoking a theoretical framework often regarded as a bastion of institutionalized homophobia, she also challenges the queer sensibility of her readers. In Sedgwick's reading, however, regarding shame as a space of identity does not entail understanding identities as essences. Instead, alongside the anti-identitarian mood of early 1990s queer theory, Sedgwick suggests reading the "place of identity" as identity as "to-be-constituted" and, hence, as "the question of identity" (ibid:14).

In making this general argument about shame and identity, Sedgwick combines a reading of shame as performativity with theories of developmental psychology. She draws from both contexts to argue that shame marks a threshold between inner and outer. It is "the affect that mantles the threshold between introversion and extroversion, between absorption and theatricality, between performativity and - performativity" (ibid:8). It is in this sense, as boundary-work, Sedgwick argues, that shame is "integral to and residual in the processes by which identity itself is formed"(ibid:13).

While not wanting to define shame as a queer emotion exclusively, Sedgwick nevertheless associates shame with the notion of queer, linking it both to the formation and to the questioning of sexual identities. Emphasizing the contingency of concepts, she argues for historical specificity. In her words, "at this historical moment" shame is intimately associated with "lesbian and gay worldly spaces" (ibid:13). Contending that queer does not equal homosexuality, Sedgwick nevertheless uses queer in a quasiidentitarian manner to refer to "this group or an overlapping group of infants and children, those whose sense of identity is for some reason tuned most durably to the note of shame". She ended her article in a foundational conclusion: "at least for certain ('queer') people, shame is simply the first, and remains a permanent, structuring fact of identity". In this way, shame for some is "an originary affect" from which "particular structures of expression, creativity, pleasure, and struggle" develop (ibid:13-14). Moreover, she defines the very "political potency" of the term "queer" by highlighting the childhood experience of shame as "a near-inexhaustible source of transformational energy" (ibid:4).

Both her arguments about identities in general and queer identities in particular feature a tension between a foundational argument about the importance of shame as a historical, identityforming experience and an emphasis on shame as transformational, as "the work of metamorphosis, reframing, refiguration, transfiguration, affective and symbolic loading and deformation" (ibid:13). In this manner, Sedgwick redescribes shame as a complex concept: a 
universal affect and a historically specific subject formation, an affect explaining both subjection to a norm or identity and its contestation. Sedgwick explicitly rejects readings of her article as a theory of homosexuality, but she also denies suggesting a theory of queerness 'drained of specificity or political reference' (ibid:11). Shame is at once devised as a generative and performative mechanism that engenders both queer subjection and agency, providing inspiring interpretive perspectives for many scholars.

In retrospect, Sedgwick's 1993 article indeed initiated a "turn to emotion" in queer studies, serving as a point of reference for most subsequent scholarship in the field. While tapping, perhaps, like Dottie Gets Spanked onto a momentum in queer activism, it reconceptualized the question of affect in general and shame in particular as a timely topic and a new methodological opening. If methodology is understood as a discussion of concepts, of how they are defined, used and to what ends and with what effects, Sedgwick's 1993 article is undoubtedly to be merited as initiating one of the major methodological turmoils in the history of queer scholarship.

The versatility of Sedgwick's argument is evident when regarding the broad range of queer scholarship on shame by, among others, Michael Warner (1999), Douglas Crimp (2002), Sara Ahmed (2004), Elspeth Probyn (2005), Sally Munt (2007) and Heather Love (2007). In the wake of Sedgwick's call, shame has been redescribed as a "special kind of sociality" and a mode of "collectivity of the shamed" (Warner 1999:35-6; Crimp 2002:66). The Gay Shame conference at University of Michigan (Halperin 2009) in 2003 documented this upsurge of queer scholarship on shame, testifying also to the controversy and contestation that the topic of shame has aroused. Prior to the publication of the conference presentations and discussions which were were published in 2009 (Halperin \& Straub 2009), Judith Halber- stam questioned the politics of gay shame in a 2005 Social Text special issue, "What's queer about queer studies, now?”. Questioning the agendas of the organizers and speakers of the Gay Shame conference, Halberstam criticized the queer attachment to shame as "a white gay male thing". In her reading, the reclaiming of shame tends to universalize the subject of shame, to ignore the politics of privilege at play and to disavow shame as "the gendered form of sexual abjection" (Halberstam 2005:220-226).

Notably, most authors in the Gay Shame conference anthology cite Sedgwick's 1993 essay or its revised and republished versions as their key source on shame (Halperin \& Straub 2009), and for Halberstam (2005), too, the centrality of Sedgwick as an absent, yet over-present theoretical authority was an obvious provocation. For Sedgwick herself, in the 1990s, the focus on shame was followed by a turn to affect in both a more general and more personal and selfreflexive sense.

\section{AfFect as METHODOLOGY}

In her 1997 anthology Novel gazing: queer readings in fiction, Sedgwick introduced the concepts of paranoid and reparative reading. With the notion of paranoid reading, she challenged what she perceived as the dominant mode of queer and feminist criticism: a practice of reading texts or other objects that seeks to reveal the hidden workings of power, that is, the "bad news" of homophobia they know in advance, expect to find and always end up confirming. Discussing Judith Butler's Gender trouble (1990) and D.A. Miller's The novel and the police (1988) as examples, Sedgwick identifies five characteristics for this approach (Sedgwick 2003:130ff).

Besides being anticipatory and forestalling surprise, paranoid criticism is reflexive and mimetic. A suspicious reader, in Sedgwick's analysis, ends up imitating and reproducing paranoia, submitting both the 
object of reading and one's reading to "a process of vigilant scanning". For example, "a certain, stylized violence of sexual differentiation must always be presumed or selfassumed - even, where necessary, imposed simply on the ground that it can never be finally ruled out" (ibid:130-133). As such, paranoid criticism is "a strong theory" in the sense of Silvan Tomkins: it has a wide reach and geared towards rigour. A strong theory draws its force from the wide spectrum of phenomena it accounts for by ordering "more and more remote phenomena to a single formulation" (Tomkins cited by Sedgwick 2003:134). Furthermore, Sedgwick characterizes paranoid criticism as a strong theory of "negative affects" following Tomkins. According to Tomkins, a paranoid is blocked against the general impulse to maximize positive affect, an impulse that, in this theory, is regarded as a general force within each individual. At best, a paranoid can strive for a defence, a shield against humiliation. Lastly, Sedgwick characterizes paranoid criticism as overinvested in the power of knowledge and the political efficacy of the form of exposure and critical gestures of demystification. (Ibid:133-137.)

Against this "monopolistic program of paranoid knowing" and "uniquely sanctioned methodology" (ibid:144, 126) that she criticizes as generalizing and tautological, Sedgwick casts reparative reading, a critical attitude that invests in hope, seeks positive affect, surprise and wonder and, therefore, assumes the risk of vulnerability. In Sedgwick's words: "to read from a reparative position is to surrender the knowing, anxious paranoid determination that no horror, however apparently unthinkable, shall ever come to the reader as new, to a reparatively positioned reader, it can seem realistic and necessary to experience surprise. Because there can be terrible surprises, however, there can also be good ones" (ibid:146). Such a critical attitude, Sedgwick argues, is "a vastly better position to do justice" to the complexity of "queer experience" and to practices that have been “invisible or illegible under a paranoid $o p$ tic". Rather than regularity and repetition, reparative reading is attuned to contingency (ibid:147). Moreover, instead of hatred, envy and anxiety that characterize paranoid readings, reparative reading seeks nourishment, comfort and love (ibid:127).

The metaphor of optic is significant as it suggests that Sedgwick regards these two critical positions, paranoid and reparative, as a question of choosing lens and, hence, as two alternative ways of seeing the world. It is this explicit methodological focus and the call for a new kind of research that makes her conceptual distinction so compelling. However, close-reading Sedgwick's discussion reveals (sic!) multi-layered and contradictory argumentation. While on the one hand outlining and marketing a paradigmatic shift, on the other hand she underlines the relatedness and the interdependency of the two critical positions. Furthermore, while emphasizing the need of both optics for accounting for the complexity of queer experience, Sedgwick's discussion suggests a distinction not only between more and less ethical and hence good research practice but also two distinct modes of affective queer politics.

On one level and importantly, Sedgwick suggests a paradigmatic shift in queer scholarship: a move from what she terms "recent fixation on epistemology" to "asking new questions about phenomenology and affect" (2003:17). In the introduction to Touching feeling, Sedgwick frames her focus on affect in more general terms, as a way of taking issue with the styles of criticism and theory encouraged by the linguistic turn. Here, Sedgwick reflects on her own research, distancing herself from Epistemology of the closet (1991) and coming out as having taken "a distinct step to the side of the deconstructive project of analyzing apparently non-linguistic phenomena in rigorously linguistic terms". Instead, she 
announces a desire to investigate "aspects of experience and reality that do not present themselves in propositional or even in verbal form alongside others that do" (2003:8).

Significantly and, perhaps ironically, not giving up the mode of figural reading, a central method within deconstructive criticism, Sedgwick challenges the topos of depth and exposure as governing metaphors of queer theory. The target of Sedgwick's criticism is what she terms "the methodological centrality" of "hermeneutics of suspicion" to queer criticism, "a mandatory injunction rather than a possibility among other possibilities" (2003: 124f). In the research programme she envisions, Sedgwick rejects the thrust "to expose residual forms of essentialism lurking behind apparently nonessentialist forms of analysis", "to unearth unconscious drives or compulsions underlying the apparent play of literary forms" or "to uncover violent or oppressive historical forces masquerading under liberal aesthetic guise" (ibid:8). Instead of wanting to go beneath, behind or beyond, Sedgwick gestures towards "Deleuzian interest in planar relations" and chooses beside as her favoured preposition that resists both dualism and the narrative logic of origin and telos. For Sedgwick, "Beside permits a spacious agnosticism about several of the linear logics that enforce dualistic thinking: noncontradiction or the law of the excluded middle, cause versus effect, subject versus object". However, Sedgwick hurries to specify, it does not "depend on a fantasy of metonymically egalitarian or even pacific relations". "Beside comprises a wide range of desiring, identifying, representing, repelling, paralleling, differentiating, rivalling, leaning, twisting, mimicking, withdrawing, attracting, aggressing, warping, and other relations" (ibid).

It is evident that for many, Sedgwick's discussion reads as an argument against paranoid readings as reductive form of knowledge. In the special issue of South Atlantic Quarterly, Ann Cvetkovich (2007: $462 \mathrm{f}$ ) summarizes reparative reading as "affectively driven, motivated by pleasure and curiosity, and directed towards the textures and tastes, the sensuous feel, of one's objects of study". In this way, reparative reading coincides with contemporary epistemological ideals of ethnographic and feminist research: knowledge as situated, particular and open-ended. In the same volume, Elizabeth Freeman (2007:499) articulates a protocol for this virtuous practice: "because we can't know in advance - we can know only retrospectively, if even then - what is queer and what is not, we gather and combine eclectically and idiosyncratically, dragging a bunch of cultural debris around us and stacking it in eclectic piles "not necessarily like any pre-existing whole'."

José Esteban Muñoz (2007:550) joins this reading stressing the importance of "shifting away from a hermeneutic that is primarily attuned to the epistemological". In his argument, "doing away with feminism, queerness, and race as epistemological certitudes would open a site of potentiality where these particularities exist as methodologies that free new meaning". Echoing even if not citing Sedgwick's criticism of paranoid reading, he contends: "We cannot know in advance the politics prescribed by these critical modes, and we should not". It is through "a lens that registers affective particularity, relational sensuousness, and the intricacies of belonging as friends, lovers, and beyond" that "performative opening for a new sense of the world" can be staged (ibid).

Here and elsewhere, Sedgwick's conceptual distinction has been interpreted as a $l i$ cense to "unapologetically theorize in a sentimental key" (Kelleher 2002:158). In Cvetkovich's (2007:463) words, "the embrace of affect within queer studies" has "enabled new forms of personal voice in academic work", including "overt declarations of love and other investments in our 
intellectual projects". In his recent overview of Sedgwick's thinking, Jason Edwards (2009:119) argues that she "encourages us to consider not only what texts make us think about, and what might be wrong with them, but what precise pleasures, surprises and resources texts might have to offer us, as well as how, what, where and for how long texts make us feel". Moreover, Edwards diagnoses "a profound reorientation of literary criticism from the sentence 'Shame on you' to a primary emphasis on happiness - which - if it made us more contented, undemanding, trusting, peaceful and grateful, might trigger off fewer negative, paranoidschizoid, shame-filled, affective and relational spirits" (ibid).

In these interpretations, paranoid and reparative readings are considered fundamentally different. One as a negative, destructive form of criticism; an amalgam of programmatic and ideological approaches that instead of producing "new knowledge" reproduces old truths, the same, which we already know. The other, again, open, positive, sensitive, healing, productive and innovative. Alongside the opposition of good versus bad scholarship, a distinction between ethical and unethical approaches emerges.

However, in her writing on paranoid and reparative readings Sedgwick questions the rhetoric of paradigmatic shift by underlining how paranoid and reparative critical practices are to be understood as positions and "changing and heterogeneous relational stances" rather than "theoretical ideologies" or "personality types of critics" (2003:128, 150). Indeed Sedgwick's conceptual distinction emerges from her encounter with Melanie Klein's object-relations theory, an alternative psychoanalytical tradition to those of Freud and Lacan. The notions of paranoid and reparative reading correlate with Kleinian concepts of schizoid/paranoid and depressive positions which, in Klein, are fundamentally interlinked.
"Some fluctuations between the paranoidschizoid and the depressive positions always occurs and are part of normal development. No clear division between the two stages of development can therefore be drawn; moreover, modification is a gradual process and the phenomena of the two positions remain for some time to some extent intermingled and interacting." (Klein 1997:16)

In Sedgwick's (2007:631; 2003:128) reading, Klein sees in infants and adults alike a dynamic of omnipotence and powerlessness, and emphases a "flexible to-and-fro movement" between these positions. While we are born into the fragile and violent paranoid-schizoid position and triggered by this "endogenous dread" engaged in the primary defence mechanisms of splitting, omnipotence and violent projection and introjection, in Kleinian model, "middle ranges of agency - the notion that you can be relatively empowered or disempowered without annihilating someone else or being annihilated, or even castrating or being castrated" offers "a great mitigation", even if it is always a "fragile achievement that requires discovering over and over" (Sedgwick 2007:631f).

While arguing eloquently for the versatility of Kleinian psychoanalysis against Freudian theory, Sedgwick does not ground her interest in her objects of research. Rather, the focus is on the scholar herself and others - or a narrator, a subject participating in and constructed within the textual dynamic. Reading Sedgwick, two literary examples emerge as paralleling the distinction of paranoid and reparative readings as critical positions. When discussing shame in relation to queer performativity, Sedgwick's (1993) object of analysis is Henry James's The art of the novel (1934), a collection of his prefaces to New York editions of his novels. Close-reading James's prefaces, Sedgwick uncovers a dialogue and intersubjective tension between two authorial selves and subject positions: a 
younger and an older James, a depressed and a vindicated James. In Touching feeling, the final volume of Proust's $A$ la reserche $d u$ temps perdu (1913-1927) is in passing invoked as an example of reparative mode: in it, "the narrator, after a long withdrawal from society, goes to a party where he at first thinks everyone is sporting elaborate costumes pretending to be ancient, then realizes that they are old, and so is he - and is then assailed, in half a dozen mnemonic shocks, by a climactic series of joy-inducing 'truths' about the relation of writing to time" (Sedgwick 2003:148). Sedgwick closes her chapter by discussing reparation as finding comfort:

No less acute than a paranoid position, no less realistic, no less attached to a project of survival, and neither less nor more delusional or fantasmatic, the reparative reading position undertakes a different range of affects, ambitions, and risks. What we can best learn from such practices are, perhaps, the many ways selves and communities succeed in extracting sustenance from the objects of culture - even of culture whose avowed desire has often been not to sustain them. (Sedgwick 2003:150f)

In this quote, Sedgwick moves between detecting paranoid and reparative practices in culture and history and characterizing them as available, voluntary critical positions for today's queer scholars.

\section{AfFect as Hope}

The force and the weakness of Sedgwick's conceptual distinction lies in her focus on methodology. Sedgwick offers her conceptual distinction "not as a tool of differential diagnosis, but as a tool for better seeing differentials of practice" (2003:130). Her focus is on the affects of queer scholars, the affective dynamics and its consequences within the field of queer scholarship. When discussing operations of shame in Henry
James, her ultimate interest is not in how the affect is constructed or what it means in the text, but in the effects of the affective dynamic for the reading subject. Despite Sedgwick's repeated caveats, it is alluring to read her as suggesting roads to reparation for queer scholars. In the special issue of South Atlantic Quarterly, the "turn to affect" reads quite exclusively as a "turn to interiority". It is the affects of queer scholars and the "field" that are at issue. Many of the writers diagnose the affective state of queer scholarship "after" what is perceived as a loss of the transformational energy since the first ACT UP-generation and the beginnings of queer activism. The future of queer thinking, it is implied, is a matter of both therapy and critical self-reflection. In other words, the "inchoate self" to be resourced by the "additive and accretive" reparative impulse stands out as the queer scholar (Sedgwick 2003:149ff).

In her criticism of focus on gay shame, Judith Halberstam (2005) attacked the notion of affect and its elevation into a methodologically important tool within queer scholarship. She questioned "the notion that social change can come about through adjustments to the self, through a focus on interiority without a concomitant attention to the social, political, and economic relations", and described it as a potentially "a disastrous tactic for queer studies and queer activism" (Halberstam 2005:224). Halberstam related her critique to that of Lauren Berlant $(2002,2008)$ who, in her response to Sedgwick's turn to affect, has criticized the association of affect with a politics of individualism: "Must the project of queerness start 'inside' of the subject and spread out from there?" According to Berlant, individuality, "that monument of liberal fantasy, that site of commodity fetishism, that project of certain psychoanalytical desires, that sign of cultural and national modernity", is a form that needs "interruption" rather than affirmation (Berlant 2002:74). As a critic of 
"sentimentalization of culture" and the politics of intimacy, Berlant is suspicious of the "the very general sense of confidence in the critical intelligence of affect, emotion, and good intention". In her reading, this confidence shared by many feminists and queer activists results in "an orientation toward agency that is focused on ongoing adaptation, adjustment, improvisation, and developing wiles for surviving, thriving, and transcending the world as it presents itself". What this therapeutic language lacks is a possibility to traverse or translate into the political register (Berlant 2008:2). Therefore, Berlant urges us to problematize what she terms a "politics of true feeling": grounding feminist and queer politics in emotions and granting emotions a given explanatory value and status to organize "analysis, discussion, fantasy and policy" (Berlant 2000:35).

As diversely developed by Sedgwick and her followers, reparative criticism reads as an investment in hope, in futurity. As Sedgwick writes in Touching feeling: "Hope, often a fracturing, even traumatic thing to experience, is among the energies by which the reparatively positioned reader tries to organize the fragments and part-objects she encounters or creates" (2003:146). In this approach, the task of criticism is to heal, comfort and infer hope, and Sedgwick herself suggests that her turn to affect reflects a shift in the more general structure of feeling in queer communities. Whereas in the 1980s and early 1990s, the horror of the AIDS epidemic and its public framings called forth a paranoid position, the news in the mid-1990s about possibilities to treat HIV as a chronic disease brought about new perspectives and a new sense of futurity (Sedgwick 2007:638f).

In Touching feeling, Sedgwick offers reparative reading as a methodology for $b e^{-}$ side. While sharing many features with Deleuzian feminist and queer theory (Braidotti 2002, 2006; Nigianni \& Storr 2008; Colebrook 2009) - the questioning of the linguistic turn, the criticism of Judith Butler and her followers, the focus on positivity and an emphasis on the ethical dimension of criticism - the Sedgwickian method is ultimately at odds with it. Importantly, the Kleinian emphasis on schizoid-paranoid and reparative positions as interrelated entails thinking along the kind of on-the-one-hand/on-the-otherhand-logic that Deleuzian approach rejects as a negotiation of a given system (Colebrook 2008:27f).

The late 1990s and early 21 st century have resulted in a mapping of queer and feminist scholars, at least implicitly and metaphorically, into two camps: those for joy, those for melancholy; those for future, those for death; those for reparative criticisms, those constrained by paranoia (Braidotti 2002, 2006; Colebrook 2008, 2009). The editors of "After sex? on writing since queer theory" have partly fallen for this dualistic rhetoric in casting 'antisocial turn' and 'turn to affect' - Lee Edelman and Eve Kosofsky Sedgwick - against one another. While this casting may seem plausible in relation to the politics of hope, various theories and implied methodologies choose or choose not to engage in, it is fundamentally inhibitive rather than productive for queer scholarship. Importantly, it conceals the politics of concept at play in a 'turn to affect' (see Koivunen 2010). While the question of affect for many scholars is a question of epistemology and methodology and, therefore, an opportunity for increased personal and political accountability, for others it reads as a possibility to move beyond the individual and personal, and to relocate critical attention from language, discourse and representations to the real, from body to matter, from cultures to nature, from identity to difference, from psychic to social. Whereas some view the concept of affect as a means to focus on the agency of the subject, others use it to displace the concept of subject and to radically rephrase the notion of agency it- 
self. If the turn to affect features a range of different concepts and concomitant methodologies, also the anti-social theory as identified with Leo Bersani and Lee Edelman has been criticized from within (Halberstam 2008).

Not acknowledging the distinctions and contradictions within the "turn to affect" (as above demonstrated in Sedgwick's own thinking and her critical legacy), the map offered by The South Atlantic Quarterly, furthermore, clouds other, perhaps more important theoretical, methodological and political faultlines within queer scholarship. Notably, it conceals the divide between theorists committed to notions of subject, language and representation and those choosing the new materialist vocabulary to voice a critical perspective of beyond and after humanism. The suggested divide renders invisible the shared theoretical and methodological grounds - deconstruction and psychoanalysis, although in different versions, are after all, central to both Sedgwick and Edelman - but it also veils the questioning of the linguistic turn and the status of psychoanalysis that cuts across the camps. Rather than clarifying key points of difference or pointing out possibilities of dialogue, the juxtaposition clouds a range of fundamental disagreements concerning the aims and stakes of queer scholarship.

Returning to Sedgwick, the divide suggested by Janet Halley and Andrew Parker unfortunately omits all the ambivalence that Sedgwick saw as the productivity of her conceptual distinction. Whether or not hope is a relevant criteria for assessing queer theory, in the contemporary situation where poststructuralist and Deleuzian critical vocabularies talk past and beyond one another, addressing each other in capital letters and with the powerful, affective metaphors of life and death, Sedgwick's modest proposal seems productive: "My own uncomfortable sense is that, for me at any rate, activist politics takes place - even at best - just at this difficult nexus between the paranoid/schizoid and the depressive positions" (Sedgwick 2007:637). A turn to affect, hence, is more than yearning for reparation and comfort as a researcher and queer subject. Following her thought, the future for queer scholarship entails a neverending movement between positions of suspicion and trust, between a "terrible alertness" to wrongs and injustices and moments of hope and comfort. Methodologically, Sedgwick offers no alternatives but suggests a political and ethical obligation to combine "schizoid" activism and self-assurance with "depressive" self-doubt and critical reflection. Moreover, this combination serves as a description of an ontological condition as both dynamics are present and potential in Sedgwick's psychoanalytic understanding of the scholarly as well as the textually constructed subject. In a Sedgwickian vein, therefore, a turn to affect is an urge not to give up the notion of subject but to continue formulating new questions about it and to continue negotiating the critical legacies of psychoanalysis. In this way, close-reading Sedgwick's version of the turn makes visible how methodology always reads as a politics of concepts.

The research for this article has been funded by Academy of Finland and conducted as a member of the Centre of Excellence in Political Thought and Conceptual Change, The Politics of Philosophy and Gender Research Team (2006-2011).

\section{Notes}

1. The article and its key ideas has been published, in revised versions, in Sedgwick 1995, Sedgwick 1997, Sedgwick 2003 and Halperin \& Traub 2009 . 


\section{LITERATURE}

- Ahmed, Sara (2004) The cultural politics of emotion. Edinburgh: Edinburgh University Press.

- Berlant, Lauren (2000) “The subject of true feeling: pain, privacy, and politics". In: Maureen McNeil et al (eds) Transformations: thinking through feminism. London: Routledge, 33-47.

. - (2002) 'Two girls, fat and thin', in Stephen M. Barber \& David L. Clark (eds) Regarding Sedgwick: essays on queer culture and critical theory. New York: Routledge, 71-108.

- - (2008) The female complaint: the unfinished business of sentimentality in American culture, Durham, NC : Duke University Press.

- Braidotti, Rosi (2002) Metamorphos: towards a materialist theory of becoming. Cambridge: Polity. - - (2006) Transpositions: on nomadic ethics, Cambridge: Polity.

- Butler, Judith (1990) Gender trouble: feminism and the subversion of identity. London: Routledge. . - (1993) "Critically queer", GLQ 1:1 (1993): 17-32.

. Colebrook, Clare (2008): "How queer can you go?". In: Queering the non/human, edited by Noreen Giffney \& Myra J. Hird. Aldershot: Ashgate 2008:17-34.

. Colebrook, Clare (2009): "On the very possibility of queer theory". In: Deleuze and queer theory, edited by Chrysanthi Nigianni \& Merl Storr. Edinburgh: Edinburgh University Press, 11-23.

. Cvetkovich, Ann (2007), "Public feelings", South Atlantic Quarterly 106 (3):459-468.

. Crimp, Douglas (2002) "Mario Montez, for shame". In: S. M. Barber \& D. L.

- Clark (eds) Regarding Sedgwick: essays on queer culture and critical theory. New York: Routledge.

- De Lauretis, Teresa (2004): The practice of love. lesbian sexuality and perverse desire. Bloomington: Indiana University Press.

- De Lauretis, Teresa (2008): Frend's drive: psychoanalysis, literature and film. Houndmills: Palgrave Macmillan.

- Edelman, Lee (2007): "Ever after: history, negativity, and the social", South Atlantic Quarterly 106 (3):469-476.

- Edwards, Jason (2009): Eve Kosofsky Sedgwick. London: Routledge.

. Freeman, Elizabeth (2007) "Still after", South Atlantic Quarterly 106 (3), 495-500.

- Freud, Sigmund (1955) "'A Child is being beaten': a contribution to the study of the origin of sexual perversions". In: The standard edition of the complete psychological works of Sigmund Freud Vol. XXVII. London: Hogarth Press, 175-204. Orig. "Ein Kind wird geschlagen". Beitrag zur
Kenntnis der Entstehung sexueller Perversionen" (1919)

- Halberstam, Judith (2005): 'Shame and white gay masculinity', Social Text 84-85:219-234.

- - (2008): "The anti-social turn in queer studies", Graduate Journal of Social Science 5 (2):140-156.

- Halley, Janet \& Andrew Parker (2007): 'Introduction' (Special issue: After sex? on writing since queer theory), South Atlantic Quarterly 106 (3):42lf

- Halperin, David M. \& Valerie Straub (2009):

"Beyond gay pride". In: Gay shame, edited by David M. Halperin \& Valerie Straub. Chicago: University of Chicago Press, 3-40.

- Halperin, David M. (2009): "Why gay shame now?". In: Gay shame, edited by David M.

Halperin \& Valerie Straub. Chicago: University of Chicago Press, 41-46.

- Kelleher, Paul (2002): "If love were all: reading Sedgwick sentimentally" in Ste-phen M. Barber \& David L. Clark (eds) Regarding Sedgwick: essays on queer culture and critical theory. New York: Routledge, 143-162.

- Klein, Melanie (1997): "Notes on some schizoid mechanisms" (1946). In: Envy and gratitude and other works 1946-1963. London: Vintage, 1-25.

- Koivunen, Anu (2010). "An affective turn? reimagining the subject of feminist theory", in Marianne Liljeström \& Susanna Paasonen (eds) Disturbing differences: working with affect in feminist readings. London: Routledge, 2010:8-29.

- Love, Heather (2007) Feeling backward: loss and the politics of queer history. Cambridge, MA: Harvard University Press.

- Miller, D.A. (1988) The novel and the police. Berkeley: University of California Press.

- Muñoz, Jose Esteban (2007) "The sense of watching tony sleep", South Atlantic Quarterly 106 (3):543-552.

- Munt, Sally R. (2007) Queer attachments: the cultural politics of shame. Aldershot: Ashgate.

- Nigianni, Chrysanthi \& Storr, Merl (2008): "Introduction". In: Deleuze and queer theory, edited by Chrysanthi Nigianni \& Merl Storr. Edinburgh: Edinburgh University Press, 1-10.

- Probyn, Elspeth (2005) Blush: faces of shame. Minneapolis: University of Minnesota Press. - Sedgwick, Eve Kosofsky (1993): “Queer performativity: Henry James's The art of the novel", GLQ 1:1 (1993), 1-16.

. - \& Adam Frank (1995) 'Shame in the cybernetic fold: reading Silvan Tomkins', in E. Sedgwick \& Adam Frank (eds) Shame and its sisters: a Silvan Tomkins reader. Durham, NC: Duke University Press. 
- - ed. (1997) Novel gazong: queer readings in fiction. Durham, NC: Duke Uni-versity Press. - - (2003) Touching feeling: affect, pedagogy, performativity. Durham, NC: Duke University Press. - - (2007) "Melanie Klein and the difference affect makes", South Atlantic Quarterly 106 (3), 625642 .

- Stockton, Kathryn Bond (2006) Beautiful bottom, beautiful shame. where "black" meets "queer". Durham: Duke UP, 2007.

- Warner, Michael (1999): The trouble with normal: sex, politics, and the ethics of queer life. Cambridge, MA: Harvard University Press.

This article was first published in lambda nordica 2010, 3-4.

\footnotetext{
AbSTRACT

Artikeln undersöker den så kallade affektiva vändningen som enligt ett specialnummer av South Atlantic Quarterly, "After sex? on writing since queer theory" (2007), kännetecknar även queerforskning på 2000talet. Artikeln ifrågasätter existensen av "en vändning” genom en närläsning av Eve Kosofsky Sedgwicks inflytelserika skrifter om skam samt om paranoida och reparativa läsesätt. Såväl Sedgwicks förståelse av skam som bennes uttalat metodologiska reflexioner kring queerforskning kännetecknas av kom-
}

plexitet och ambivalens. Detta bottnar $i$ hennes psykoanalytiska referensram och koppling av affektbegreppet till subjektteori, till skillnad frain t.ex. nymaterialistiska ansatser. Som en följd kan hennes idéer om paranoida och reparativa positioner svarrligen tolkas som två väsensskilda metodologiska alternativ eller en värdering av två valbara, sinsemellan alternativa läsesätt. Sedgwicks begreppspar kan inte heller reduceras till en inbjudan till forskare att "tala om" känslor och upplevelser. I stället kan dessa två positioner, förankrade $i$ Melanie Kleins psykoanalytiska teori, med fördel uppfattas som en beskrivning av det queera forskarsubjektets ontologiska situation: dess nödvändiga pendling mellan negativ och positiv hermeneutik, mellan kritisk granskning och ifrågasättande av denna attityd, mellan tvivel och hopp $i$ sitt förhallande till världen. I Sedgwicks tapp-ning innebär "affektiv vändning” en utveckling av subjektteorier. Hennes skrifter deltar $i$ utmaningen av den förra, lingvistiska vändningen men deltar $i$ dess dekonstruktion och vidareutveckling inifrain, med dess kännetecknande teoretiska verktyg, psykoanalys, dekonstruktion och närläsning.

Anu Koivunen

Associate Professor,

Department of Cinema Studies, Stockholm. 